\title{
POPULATION STRUCTURE OF AN ENDEMIC FISH LIMIA ZONATA (CYPRINODONTIFORMES: POECILIINAE) IN THE MAIMÓN RIVER, DOMINICAN REPUBLIC
}

\section{Estructura poblacional del pez endémico Limia zonata (Cyprinodontiformes: Poeciliinae) en el río Maimón, República Dominicana}

\author{
Patricia Torres-Pineda ${ }^{1}$, Carlos M. Rodríguez-Peña ${ }^{2}$, \\ Óscar M. Lasso-Alcalá ${ }^{3} \&$ Arlen Marmolejo ${ }^{2}$
}

\begin{abstract}
${ }^{1}$ Museo Nacional de Historia Natural "Prof. Eugenio de Jesús Marcano", Plaza de la Cultura, Santo Domingo, 10204.p.torres@mnhn.gov.do.

${ }^{2}$ Escuela de Biología, Universidad Autónoma de Santo Domingo, Av. Alma Mater, Santo Domingo, 10105. carlosrguez96@gmail.com, amarmolejo86@uasd.edu.do.

${ }^{3}$ Museo de Historia Natural La Salle, Caracas, Venezuela, 1930. oscar.lasso@fundacionlasalle.organización.ve.
\end{abstract}

\section{ABSTRACT}

The population structure of Limia zonata (Nichols, 1915) was studied in four locations in the Maimón River, Monseñor Nouel province, Dominican Republic. The sex and adult-juveniles ratio was calculated for all sampled localities. It was found that the sex ratio of L. zonata was significantly different from 1: 1 and is biased towards females (1.0:1.6). Juvenile fish were more abundant and frequent than adults (69.3\%). More than 800 fish were measured and weighed to analyze the frequency of size classes, morphometry and body condition. Ten size classes were distinguished that vary in frequency according to sex. Total length of the specimens ranged from 6.50 to $65.69 \mathrm{~mm}$, while weight varied between 0.004 and $3.941 \mathrm{~g}$. The morphology varied between sexes and a pronounced sexual dimorphism was found. All the morphometric variables studied showed a high level of association $(r)$. The adjustment of the regression models $\left(r^{2}\right)$ of the morphometric relationships was between $85 \%$ and $99 \%$. The relationship between the standard length and the total weight was reflected in the rates of growth. The Relative Condition Factor $(\mathrm{K} n)$ demonstrated the good state of health of this fish population, but also variations between the sexes were detected.

Keywords: Poeciliidae, Limia, sex ratio, morphometry, fluvial ecosystem.

\section{RESUMEN}

Se estudió la estructura de la población de Limia zonata (Nichols, 1915) en cuatro localidades del río Maimón, provincia Monseñor Nouel, República Dominicana. Se calculó la proporción sexual y de adultos-juveniles para todas las localidades muestreadas. Se encontró que la proporción sexual de L. zonata es significativamente diferente de 1:1 y está sesgada hacia las hembras (1.0: 1.6). Los peces juveniles fueron más abundantes y frecuentes que los adultos (69.3\%). Se midieron y pesaron más de 800 peces para analizar la frecuencia de clases de tallas, morfometría y condición corporal de la especie. Se distinguieron diez clases de tallas que variaron sus frecuencias en función del sexo. La longitud total de los ejemplares medidos estuvo dentro del rango 6.50-65.69 mm, mientras que el peso total varió entre 0.004 y 3.941 g. La morfología varió entre sexos y se encontró un marcado dimorfismo sexual. Todas las variables morfométricas estudiadas presentaron un alto nivel de asociación $(r)$. El ajuste de los modelos de regresión $\left(r^{2}\right)$ de las relaciones morfométricas estuvo entre 85 a $99 \%$. La relación longitud estándar-peso total mostró variación significativa entre los sexos, sugiriendo distintos ritmos de crecimiento. El Factor de Condición Relativo $(\mathrm{K} n)$ demostró el buen estado de salud de la población de peces, pero se detectaron variaciones entre los sexos. 


\section{INTRODUCTION}

The inland water ichthyofauna of Hispaniola is characterized by its high diversity and endemism. The livebearing fishes of the family Poeciliidae (Poeciliinae sensu Parenti, 1981) are the most diverse group, comprised of three genera: Gambusia, Poecilia, and Limia, the latter being endemic of the Greater Antilles, with one endemic species on Cuba, Grand Cayman, Jamaica and 17 described endemic species occurring on Hispaniola (Rauchenberger, 1988; Burgess and Franz, 1989; Rodríguez-Peña, 1997; Hamilton, 2001). Therefore, Hispaniola is considered the center of biodiversity for Limia and it is widely distributed on the island, occupying diverse habitats, such as freshwater mountain streams as well as coastal hypersaline lagoons. In spite of its diversity, high level of endemism and the variability of habitats in which they occur, the knowledge of the ecology and natural history of these fishes in Hispaniola is limited.

Limia zonata (Nichols, 1915) is a livebearing freshwater fish endemic to the Dominican Republic and is characterized by an elongated body, truncated caudal fin with dark lateral spots and a blunt mouth. Males have dark transverse stripes and the dorsal fin tends to have yelloworange and black coloration. The gonopodium is longer than the head and has a large genital palp. Females have a caudal peduncle which is more elongated than in other species of the genus, except for Limia versicolor, a sister species (Fig. 1), and the gonopore is covered by "chastity scales", which have not yet been described in the literature (C. M. Rodríguez, personal observation). Its range of occurrence includes the northeast, northwest and parts of the southeast regions of the Dominican Republic. This species is classified as vulnerable (VU) according to Ministerio de Medio Ambiente y Recursos Naturales (MIMARENA, 2011).

A few authors have evaluated demographic parameters in populations of Poeciliinae in the new world (Haskins et al., 1961; Snelson and Wetherington, 1980; Turner and Snelson, 1984; Contreras-MacBeath and Ramírez-Espinoza, 1996; Gómez-Márquez et al., 1999, 2008; Cabral and Marques, 1999; Montag et al., 2011; Zúñiga-Vega et al., 2012; Ramírez-García et al., 2018). However, basic demographic characteristics of most poeciliid fish populations remain unknown. Cohen et al., 2015, conducted a comparative study of life history of several Limia species, including L. zonata. Most of Limia species occur in habitats threathened by human intervention, which increases the need of a better undestanding of demographic traits of these populations towards a better management of Hispaniola's fish fauna and its habitats. This present study is the first one to explore basic demographic parameters of an endemic fish and serves as a baseline for future studies in Hispaniola.

\section{OBJECTIVE}

-To determine the population structure of Limia zonata in the Maimón River.

\section{MATERIALS AND METHODS}

Study area. The Maimón River is located in the Yuna River basin, in the southern Cibao region of the Dominican Republic. This river flows from its headwaters at the Loma La Humeadora National Park in Monseñor Nouel province and extends through the municipalities of Piedra Blanca and Maimón, until its confluence with Yuna River in Sánchez Ramírez province, where its waters feed the Hatillo reservoir in Aniana Vargas National Park (Fig. 2). The Maimón River is $33.62 \mathrm{~km}$ long and covers an approximate area of $99.49 \mathrm{~km}^{2}$ (data calculated with the watershed layers supplied by the Department of Geomatics of MIMARENA and analyzed in Quantum GIS version 2.18). Four sampling locations along the Maimón River were chosen, including headwaters (Los Plátanos locality), mid-course (Piedra Blanca and Maimón localities) and mouth (Confluencia). 
Methodology. We conducted four expeditions (two consecutive days each) to the study area between March and June 2017, which is considered the transition period from the dry season to the rainy season.

In each locality, three sampling stations were established, in which different fishing methods were used to maximize capture of the species, as well as to include the largest number of microhabitats. The stations were described qualitatively, based on type of substrate, presence of aquatic or marsh vegetation and water transparency as well as water current velocity $(\mathrm{m} / \mathrm{s})$. These sampling areas were georeferenced with a geographical positioning device Garmin GPS 76. The physical-chemical characteristics of water, including salinity $(\mathrm{ppm}), \mathrm{pH}$, conductivity $(\mathrm{mS} / \mathrm{cm})$, temperature $\left({ }^{\circ} \mathrm{C}\right)$, dissolved oxygen $(\mathrm{mg} / \mathrm{L})$ and total dissolved solids $(\mathrm{mg} / \mathrm{L})$ were measured with a YSI Professional Plus multiparameter.

Sampling stations presented sand, gravel, pebbles and mud substrate. Los Plátanos locality (headwaters) presented the highest water transparency, with clarity decreasing downstream. Aquatic vegetation was found just in Piedra Blanca and Maimón (the middle course sites). Water current velocity ranged from 0.03 to $0.57 \mathrm{~m} / \mathrm{s}$. Water temperature ranged from $21.2^{\circ} \mathrm{C}$ to $30.5^{\circ} \mathrm{C}$, and $\mathrm{pH}$ was 6.7 to 8.3 . Conductivity ranged from 92.0 to $205.5 \mathrm{mS} / \mathrm{cm}$, dissolved oxygen concentration ranged from 5.9 to $9.1 \mathrm{mg} / \mathrm{L}$. Total dissolved solids ranged from 58.5 to $121.5 \mathrm{mg} / \mathrm{L}$. All sites presented some level of impact from agriculture and cattle grazing, as well as solid wastes in water and at the river banks (Table I).

For fish sampling were used a beach net of $5 \mathrm{~mm}$ mesh, $1.25 \mathrm{~m}$ high and $3.5 \mathrm{~m}$ long, a hand net of $3 \mathrm{~mm}$ and minnow traps with $0.64 \mathrm{~cm}$ mesh, which were kept in the water for a period of six hours. Fish were fixed in 5\% formalin.

Laboratory work. The specimens collected were processed in the Vertebrate laboratory of the National Museum of Natural History "Prof. Eugenio de Jesús Marcano" (MNHNSD). Fish were washed in tap water until the formalin was removed and then preserved in $70 \%$ ethanol. Sex was determined based on macroscopic inspection of the anal fin and urogenital area. The individuals with a gonopodium were classified as males; fish that showed a rounded and bulging ventral region or presence of chastity scales in their urogenital zone were classified as females. In some cases, a ventral cut was made to verify the presence or absence of embryos. Individuals without evidence of secondary sexual characters were classified as juveniles.

Morphometric variables were described based on the measurements and weights of a random sample of individuals representing $20 \%$ of the total number of specimens. Each fish was individually numbered and fish were selected using a random number generator, so that each fish had the same probability of being selected. The morphometric variables that were measured for each individual were: total length (TL), standard length (SL) and height (HT). Lengths were measured using a Stanley digital caliper $( \pm 0.01 \mathrm{~mm})$. Total weight (WEIGHT) was recorded with a Gemini-20 digital balance $( \pm 0.001 \mathrm{~g})$.

Statistical analysis. The sex ratio was calculated as: $\mathrm{M} / \mathrm{H} * 100$, where $\mathrm{M}=$ number of males and $\mathrm{H}=$ number of females. The proportion of adults-juveniles was estimated as: A / J * 100, where $\mathrm{A}=$ number of adult fish, $\mathrm{J}=$ number of juvenile fish. The degree of statistical significance of the sex ratio as a function of the sampled localities was checked with a Chi-square test $\left(\mathrm{X}^{2}\right)$. The distribution and frequency of the size classes of the population according to sex was determined following Sturges (1926). 
Measurements of central tendency and dispersion of the morphometric variables were calculated and plotted. The morphometric measurements between females, males, and juveniles were compared by analysis of variance (ANOVA). The 95\% confidence intervals for each variable were estimated with the nonparametric bootstraping method with 1000 repetitions, using 'boot'(Canty and Ripley, 2017) a package of the statistical software R version 1.1.423 (R Development Core Team, 2016).

By means of dispersion charts and regression models between the variables studied, the model that best describes the relationship between them was identified. The degree of association between the variables was obtained by the Pearson correlation coefficient $(r)$. With an analysis of covariance (ANCOVA) it was determined if these relationships were significantly different depending on the sexes.

The Length-Weight relationship for the population was adjusted by a potential relationship of the type: $\mathrm{W}=a \mathrm{~L}^{b}$, where: $\mathrm{W}=$ total weight $(\mathrm{g}), \mathrm{L}=$ standard length $(\mathrm{mm})$, $b$ is the growth exponent or length-weight factor (or allometry coefficient) and $a$ is a constant. The relative condition factor was determined using the equation: $\mathrm{K} n=\mathrm{W}_{\mathrm{o}} / \mathrm{W}$ ' (Le Cren, 1951) where $\mathrm{K} n=$ is relative condition factor, $\mathrm{W}_{\mathrm{o}}=$ observed weight $(\mathrm{g}), \mathrm{W}^{\prime}=$ predicted weight. Where $\mathrm{W}^{\prime}=$ is $\mathrm{a} \mathrm{L}^{b}$.

The statistical software Minitab version 18 and MS Excel 2017 were used for data analysis. All statistical tests were done with a level of significance of $5 \%(p<0.05)$.

Table I. Physical and chemical water characteristics (mean \pm standard deviation) for each study locality in the Maimón River.

\begin{tabular}{|l|l|c|c|c|c|c|l|}
\hline \multicolumn{1}{|c|}{ Localities } & TEMP $\left({ }^{\circ} \mathrm{C}\right)$ & $\begin{array}{c}\text { COND } \\
(\mathbf{m S} / \mathbf{c m})\end{array}$ & $\mathbf{S A L}(\mathbf{p p t})$ & $\mathbf{p H}$ & $\begin{array}{c}\mathbf{D O} \\
(\mathbf{m g} / \mathbf{L})\end{array}$ & $\mathbf{T D S} \mathbf{( m g / L )}$ & $\mathbf{C V}(\mathbf{m} / \mathbf{s})$ \\
\hline Los Plátanos & $23.7 \pm 1.0$ & $103.6 \pm 2.3$ & $0.05 \pm 0.0$ & $7.7 \pm 0.3$ & $8.1 \pm 0.4$ & $69.0 \pm 1.6$ & $0.41 \pm 0.1$ \\
\hline Piedra Blanca & $22.3 \pm 1.4$ & $120.8 \pm 3.0$ & $0.05 \pm 0.0$ & $8.1 \pm 0.1$ & $8.8 \pm 0.2$ & $82.8 \pm 0.5$ & $0.42 \pm 0.2$ \\
\hline Maimón & $24.8 \pm 1.4$ & $118.9 \pm 15.8$ & $0.06 \pm 0.0$ & $7.5 \pm 0.5$ & $7.4 \pm 0.5$ & $77.9 \pm 12.0$ & $0.15 \pm 0.1$ \\
\hline Confluencia & $28.3 \pm 1.5$ & $196.7 \pm 5.4$ & $0.09 \pm 0.0$ & $7.2 \pm 0.2$ & $6.4 \pm 0.5$ & $120.0 \pm 1.1$ & $0.03 \pm 0.0$ \\
\hline All localities & $24.8 \pm 2.6$ & $135.0 \pm 37.9$ & $0.06 \pm 0.01$ & $7.7 \pm 0.4$ & $7.7 \pm 1.0$ & $88.2 \pm 20.7$ & $0.3 \pm 0.2$ \\
\hline
\end{tabular}

TEMP: water temperature; COND: conductivity; SAL: salinity; pH: pH; DO: dissolved oxygen; TDS: total dissolved solids; CV: Current Velocity. 


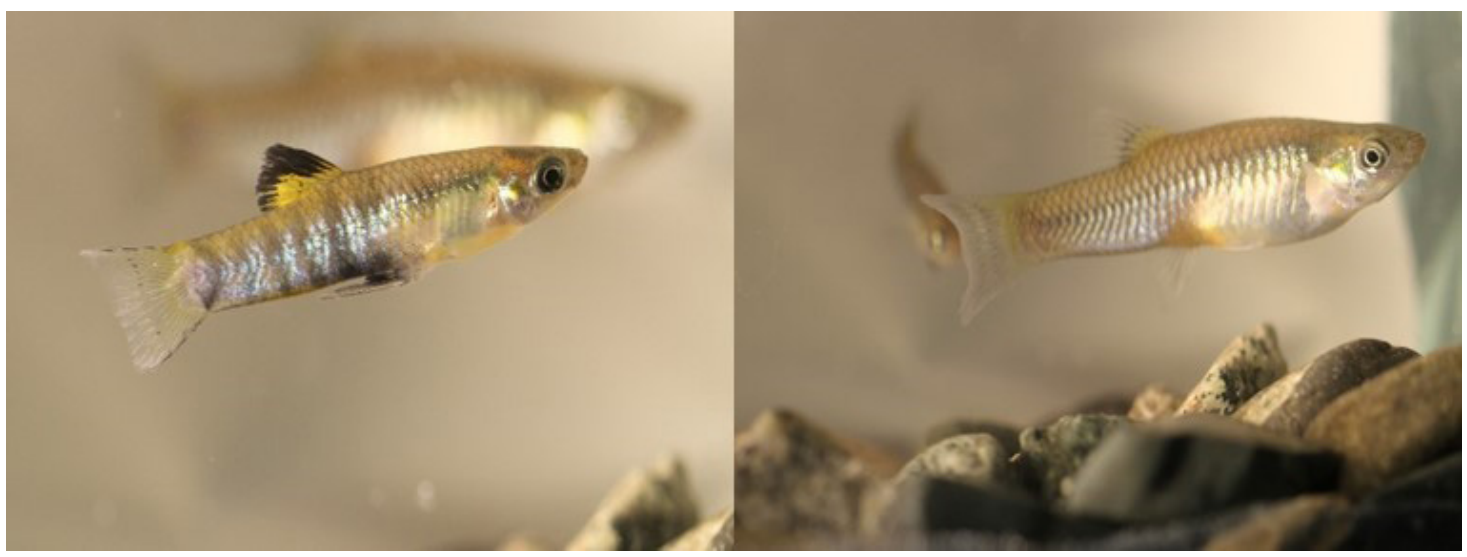

Figure 1. Limia zonata. Left, male; right, female.

\section{RESULTS}

Sex ratio and adult-juvenile ratio. 4292 individuals of L. zonata were captured, 1319 (30.7\%) of which were adults, including 810 females (61.4\%) and 509 males (38.6\%). This results in a male-female ratio of 1.0: 1.6. This proportion differs significantly from an expected sex ratio of 1: $1\left(\mathrm{X}^{2}=68.69, p<0.001\right)$. Sex ratio did vary significantly with locality $\left(\mathrm{X}^{2}=37.60, p<0.001\right)$. The sex ratio was biased towards females in all localities except for the Confluencia locality, where the proportion of males was higher (1: 0.2$) .69 .3 \%$ of the individuals were juvenile (2 973). These were more frequent than adults with a ratio of $1: 2.3$ in the entire sample, without exceptions among localities (Table II).

Size classes. Ten size classes were created based on the standard length (SL) data, with a class size of $5 \mathrm{~mm}$. The females and the juveniles were represented in a wide range of classes. These two groups occupied six of the ten size classes, while males only three. The most frequent size class was $14-18 \mathrm{~mm}(27.9 \%)$, and was occupied by young individuals $(98.8 \%)$ and males $(1.2 \%) .41 .3 \%$ of all juveniles were in this class. Males were more frequent in the size class 24-28 mm (46.8\%) and 19-23 mm (35.5\%). Females were more frequent in the classes 29-33 $\mathrm{mm}(21.1 \%)$ and $34-38 \mathrm{~mm}(20.4 \%)$. There was a significant overlap of size classes between juveniles and males, since they occupied the lower size classes (Fig. 3).

Morphometry. The morphometric data is based on a random sample of $20 \%$ of all captured specimens, corresponding to a total of 877 individuals: 143 males, 147 females and 587 juveniles. Total length (TL) of L. zonata varied from 6.50 to $65.59 \mathrm{~mm}$, with an average of $28.09 \mathrm{~mm}$ (95\% CI: 27.28-28.80 mm). Standard length (SL) had a maximum of $53.79 \mathrm{~mm}$ and a minimum of $4.38 \mathrm{~mm}$ and an average of $23.56 \mathrm{~mm}$ (95\% CI: 21.96-23.23 mm). Height (HT) varied from $1.06 \mathrm{~mm}$ to $15.9 \mathrm{~mm}$ with an average of $4.70 \mathrm{~mm}$ (95\% CI: $4.52-4.88 \mathrm{~mm})$. Total weight (WEIGHT) of the population varied from 0.004 to $3.941 \mathrm{~g}$ with an average of $0.383 \mathrm{~g}$ (CI 95\%: 0.347-0.428 g), (Table III).

The analysis of variance (ANOVA) revealed the existence of significant variation between females, males, and juveniles (ANOVA $\left.{ }_{\mathrm{TL}}: \mathrm{F}=1008.16, p<0.001\right)$, (ANOVA ${ }_{\mathrm{SL}}: \mathrm{F}=1008.79$, $p<0.001),\left(\right.$ ANOVA $\left._{\mathrm{HT}}: \mathrm{F}=965.15, p<0.001\right),\left(\right.$ ANOVA $\left._{\text {WEIGHT }}: \mathrm{F}=612.31, p<0.001\right)$. 
In an analysis by sex, females were significantly larger, higher, and heavier than males. They had an average TL of $47.63 \mathrm{~mm}$ (95\% CI: 46.09- $49.07 \mathrm{~mm}$ ) and average SL of $38.62 \mathrm{~mm}$ (95\% CI: 37.37-39.95 mm), respectively. The average HT was $9.17 \mathrm{~mm}$ (95\% CI: 8.77- 9.61 $\mathrm{mm})$ and average WEGHT of $1.446 \mathrm{~g}(95 \% \mathrm{CI}: 1.295-1.614 \mathrm{~g})$. Males had an average of TL and SL of $31.99 \mathrm{~mm}$ (CI 95\%: 31.23-32.73 mm) and 25.43 mm (CI 95\%: 24.86-26.06 mm), respectively. Height had an average of $5.91 \mathrm{~mm}$ (95\% CI: 5.69-6.13 mm). Males weighed on average $0.337 \mathrm{~g}$ (CI 95\%: 0.312-0.362 g), (Table III and Fig. 4).

Morphometric relationships. Pearson correlation coefficients $(r)$ were obtained for all the morphometric variables, all the combinations showed a high $r$ value, this means that the morphometric variables have a high degree of association. All the relationships had a value of $p<0.001$, which shows that the results are significant (Table IV).

It was found that the standard length (SL) and total length (TL) match a linear regression model with a coefficient of determination $\left(r^{2}\right)$ of $0.993(99.3 \%)$, (Fig. 5). The predictive equation of this linear relationship for the whole population is:

$$
\mathrm{TL}=0.5380+1.221 \mathrm{SL}
$$

It was found that the regression model between SL and HT is linear, the prediction equation for the whole population is:

$$
\mathrm{HT}=-1.603+0.2794 \mathrm{SL}
$$

The relationship between SL and WEIGHT is adjusted to a potential regression model, with a coefficient of determination $\left(r^{2}\right)$ of $0.938(93.8 \%)$ (Fig. 6). The prediction equation of the relation for the whole population was obtained as:

$$
\text { WEIGHT }=0.00005 \text { SL } 3.03
$$

The analysis of covariance (ANCOVA) of the relationship SL and WEIGHT between sexes showed that there are significant differences between them $(\mathrm{F}=15.17, p<0.05)$, and separate regression analysis were conducted (Fig. 7). The values of the regression slope or allometric coefficient $(b)$ varied from 2.79 to 3.24 .

Next, the predictive equations are presented according to sex:

$$
\begin{aligned}
& \text { Males }=0.00002 \mathrm{SL}^{3.05} \\
& \text { Females }=0.000009 \mathrm{SL}^{3.24} \\
& \text { Juveniles }=0.00003 \mathrm{SL}^{2.79}
\end{aligned}
$$

Relative body condition factor. The relative condition factor $(\mathrm{K} n)$ for the population of $L$. zonata had an average of 1.11. It varied between 0.42 to 1.80 in females and in males from 0.38 to 1.40 . The females showed a higher condition factor than the males with an average of 1.01 and 0.82 , respectively. However, juveniles had the highest relative condition factor with an average of 1.21 (Table V and Fig. 8). 


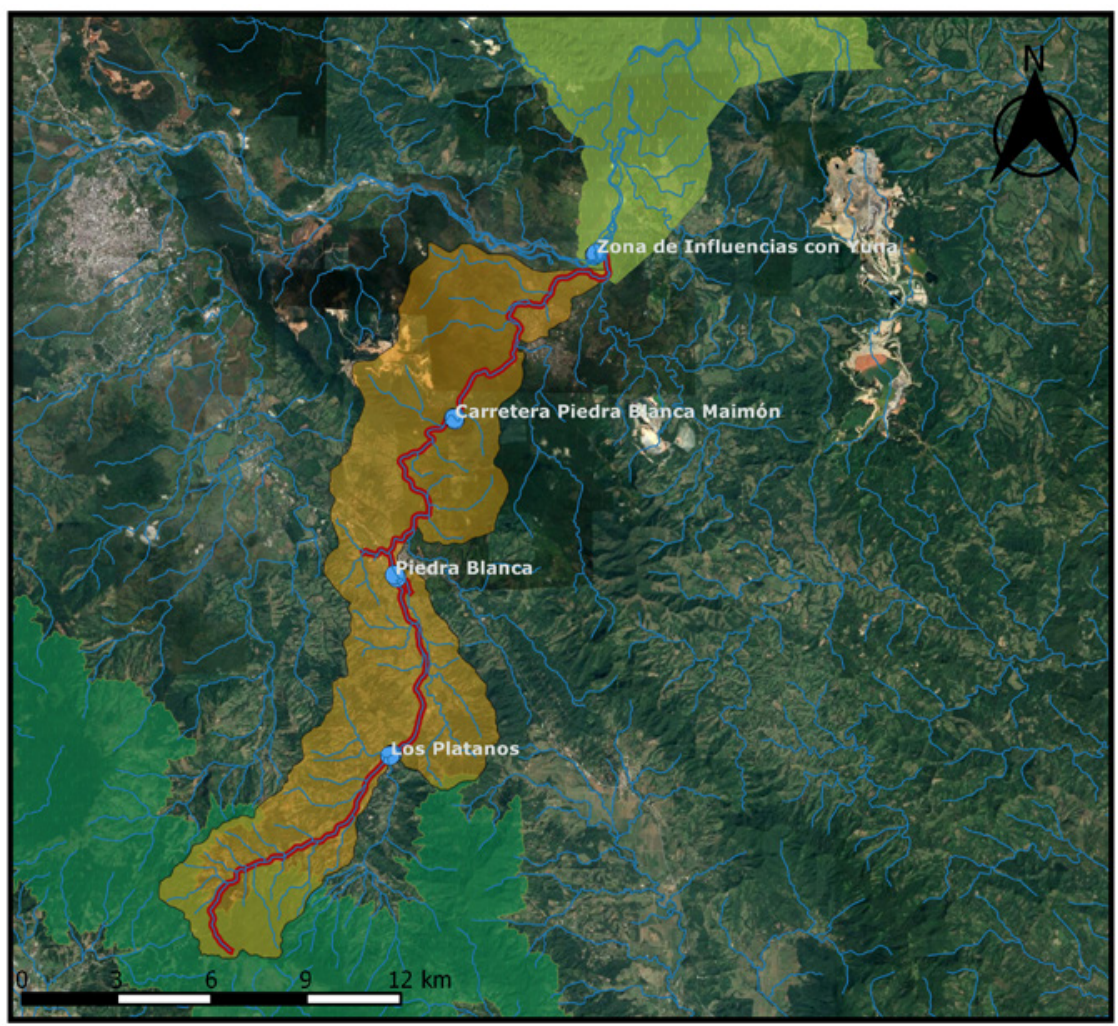

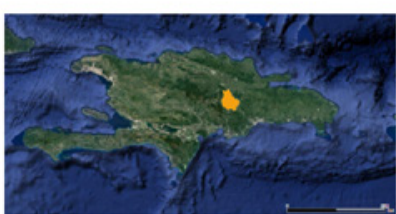

Province: Monseñor Nouel

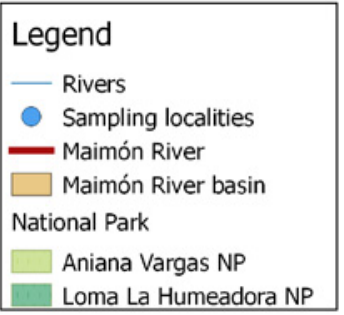

Figure 2. The Maimón River map.

Table II. Sex and adult-juvenile ratio and proportions

\begin{tabular}{|c|c|c|c|c|}
\hline Localities & M:F ratio & M-F \% & A:J ratio & A-J \% \\
\hline \multirow{2}{*}{ Piedra Blanca } & \multirow{2}{*}{$1: 1.7$} & 34.5 & \multirow{2}{*}{$1: 1.8$} & 36.3 \\
\hline & & 66.5 & & 63.7 \\
\hline \multirow{2}{*}{ Maimón } & \multirow{2}{*}{$1: 1.7$} & 37.5 & \multirow{2}{*}{$1: 2.6$} & 28 \\
\hline & & 62.5 & & 72 \\
\hline \multirow{2}{*}{ Confluencia } & \multirow{2}{*}{$1: 0.2$} & 61.4 & \multirow{2}{*}{$1: 1.1$} & 46.4 \\
\hline & & 38.6 & & 53.6 \\
\hline \multirow{2}{*}{ All localities } & \multirow{2}{*}{$1: 1.6$} & 36.2 & \multirow{2}{*}{$1: 2.3$} & 30.7 \\
\hline & & 63.8 & & 69.3 \\
\hline
\end{tabular}




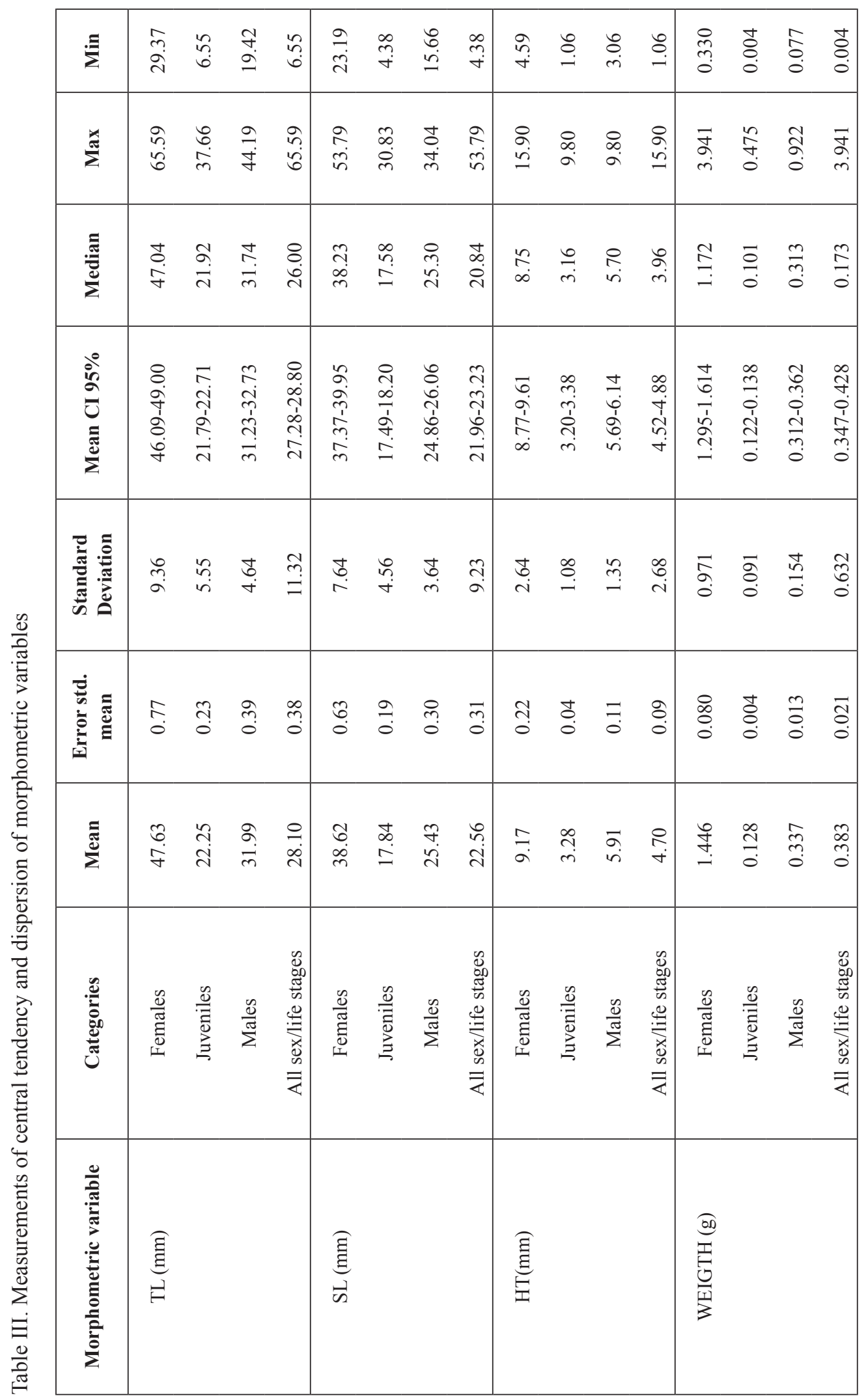


Table IV. Pearson's Correlation Coefficient $(r)$ between morphometric variables

\begin{tabular}{|lccc|}
\hline & TL & SL & HT \\
\hline SL & 0.997 & & \\
HT & 0 & & \\
& 0.967 & 0.963 & \\
WEIGHT & 0 & 0 & 0.895 \\
& 0.876 & 0.875 & 0 \\
Cell's contents & 0 & 0 & \\
$\quad \begin{array}{l}\text { Pearson's correlation } \\
\text { p value }\end{array}$ & & & \\
\hline
\end{tabular}

Table V. Measurements of central tendency and dispersion of the Relative condition factor $(\mathrm{K} n)$

\begin{tabular}{|c|c|c|c|c|c|c|c|}
\hline Variable & Categories & Mean & $\begin{array}{c}\text { Error std. } \\
\text { mean }\end{array}$ & $\begin{array}{c}\text { Standard } \\
\text { Deviation }\end{array}$ & Median & Max & Min \\
\hline \multirow{3}{*}{ Kn } & Females & 1.01 & 0.02 & 0.21 & 0.98 & 1.80 & 0.42 \\
& Males & 0.82 & 0.01 & 0.10 & 0.80 & 1.40 & 0.38 \\
& Juveniles & 1.21 & 0.02 & 0.56 & 1.11 & 5.46 & 0.12 \\
& All & 1.11 & 0.02 & 0.49 & 1.04 & 5.46 & 0.12 \\
\hline
\end{tabular}

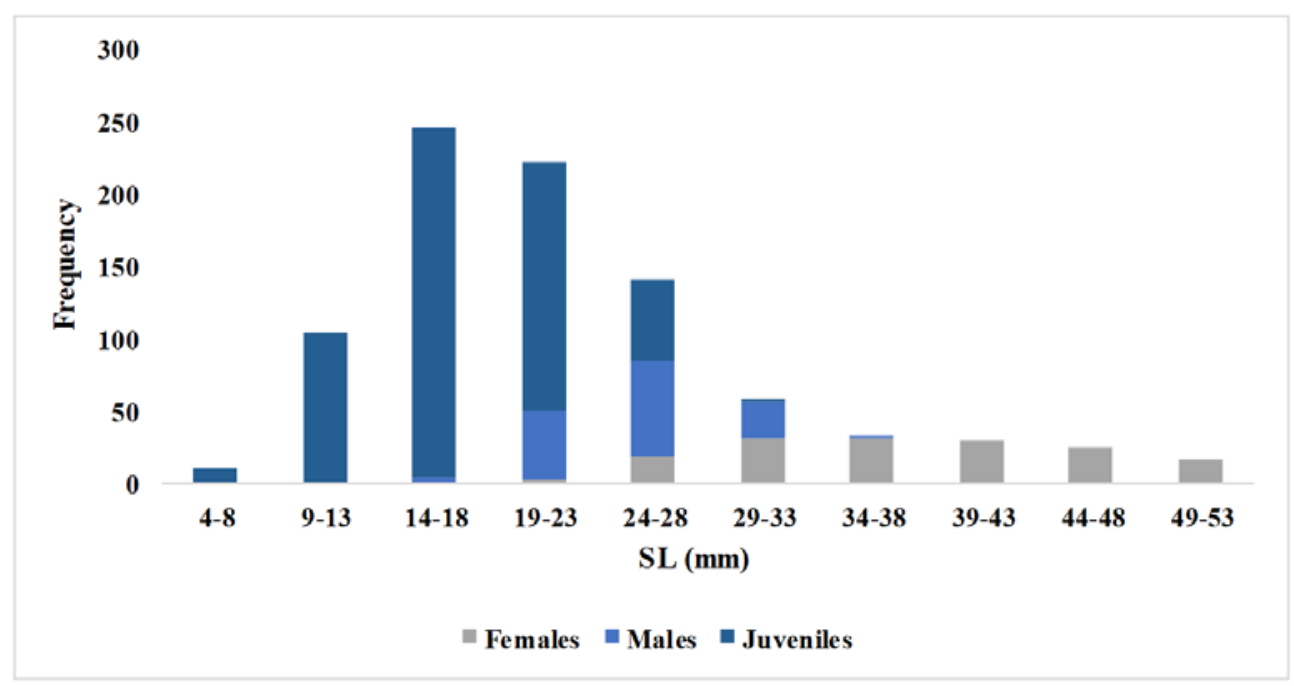

Figure 3. Frequency of size classes of Limia zonata. 

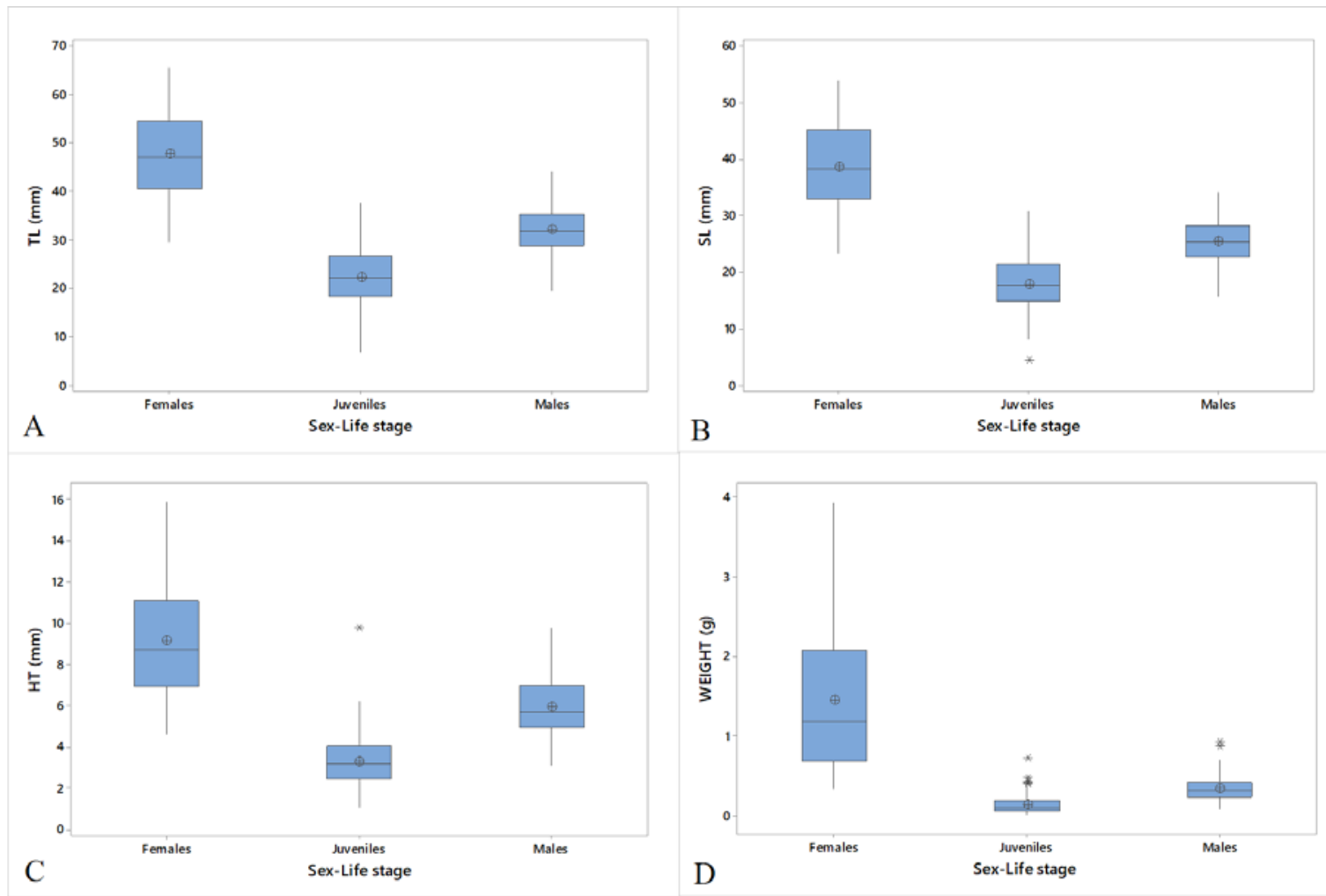

Figure 4. Boxplots of morphometric variables of Limia zonata. Shows the dispersion of the values depending on the sex or life stage. The middle line shows the median and the circle the mean. The extreme values are presented by asterisks. A. Total length (mm); B. Standard length (mm); C. Height (mm); D. Total Weight (g).

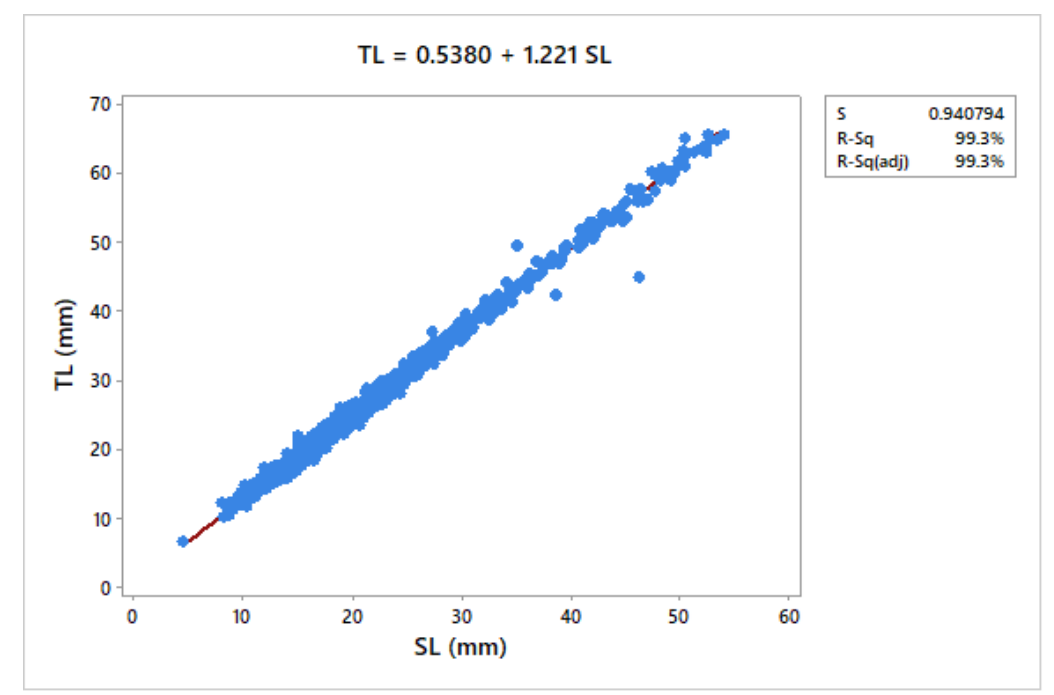

Figure 5. Total length-Standard length relationship of Limia zonata. 


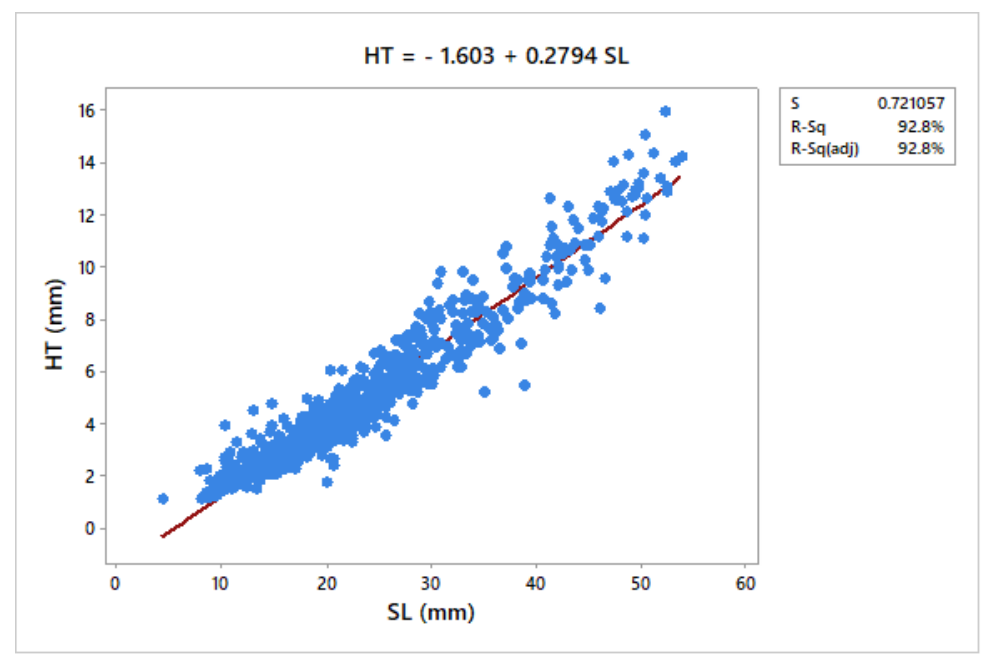

Figure 6. Height-Standard length relationship of Limia zonata.
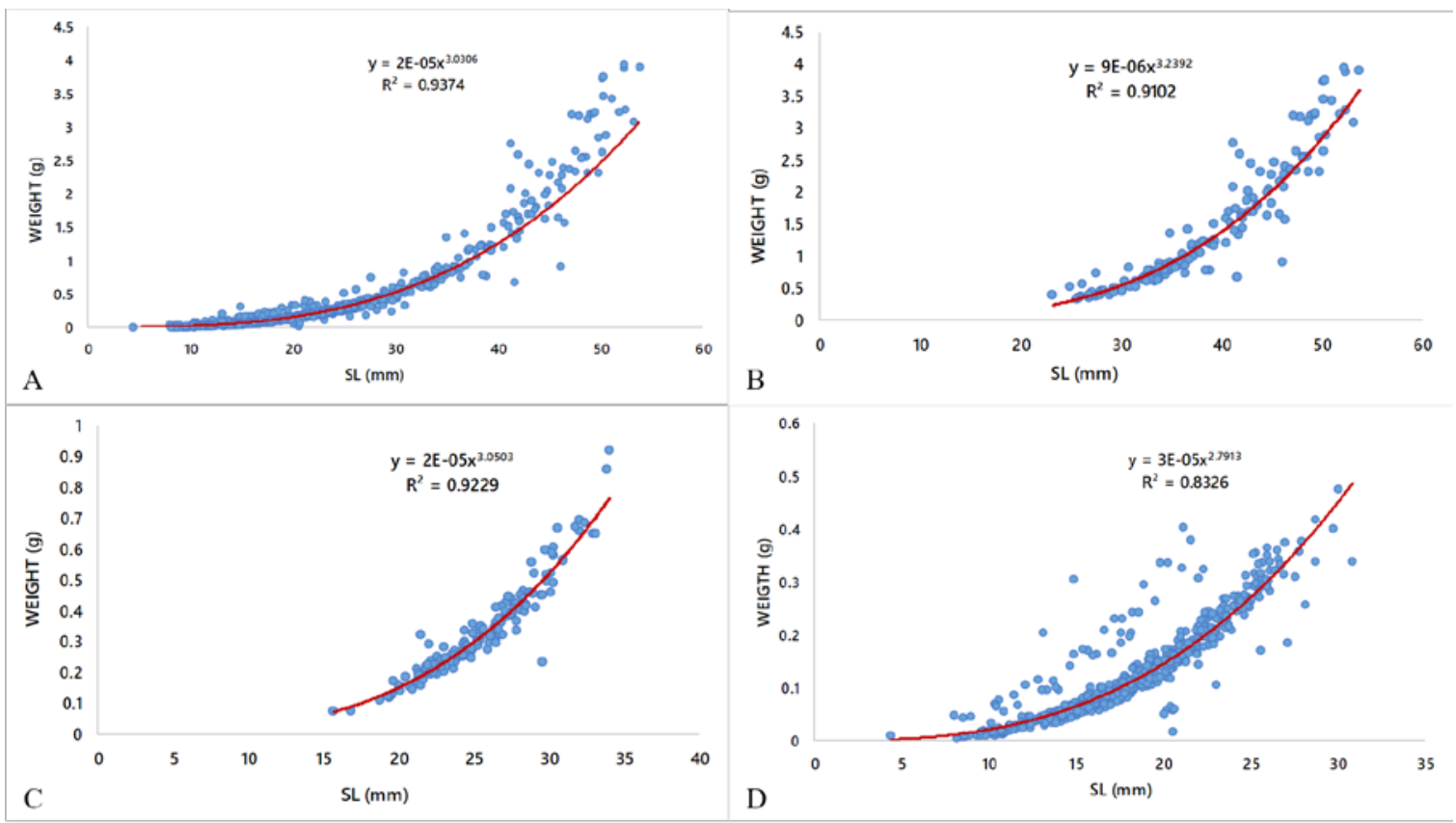

Figure 7. Total weight-Standard length relationship of Limia zonata. A. All population; B. Females; C. Males; D. Juveniles. 


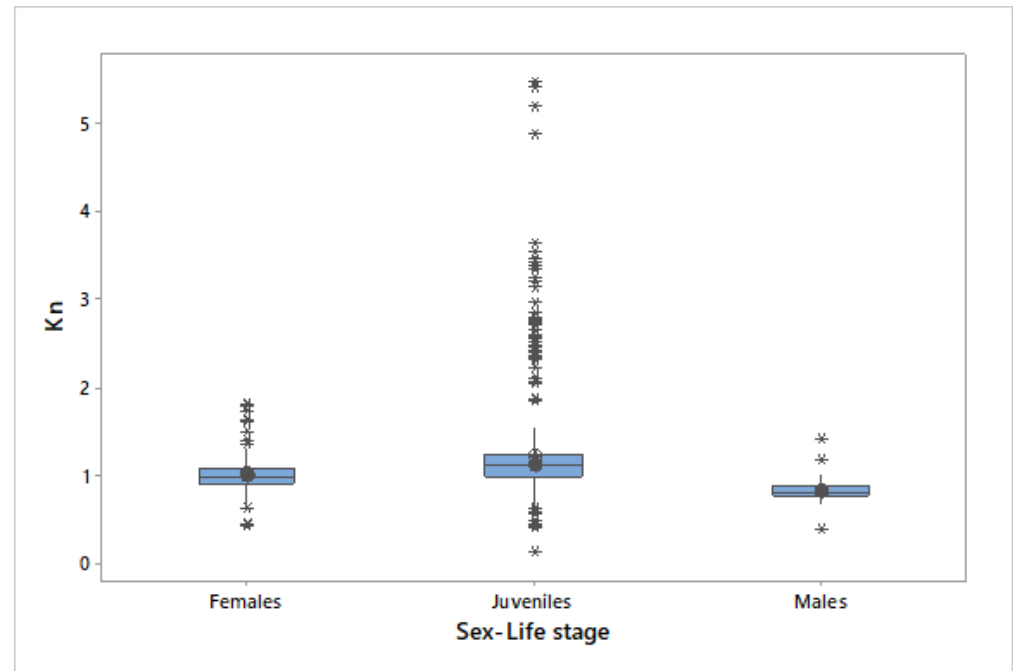

Figure 8. Boxplots of relative condition factor of Limia zonata. Shows the dispersion of the values depending on the sex or life stage. The middle line shows the median and the circle the mean. The extreme values are presented by asterisks.

\section{DISCUSSION}

Sex ratio. In the population of $L$. zonata studied there was a predominance of females, with an average of 16 females for every 10 males. Fisher (1930) suggested that the expected sexual proportion for most sexual organisms in the wild is close to $1: 1$. However, our results in this study coincide with work done on other species of Poeciliidae, which also found a greater proportion of females over males (Reza and Díaz, 1994; Contreras-MacBeath and RamírezEspinoza, 1996; Vargas and de Sostoa, 1996; Gómez-Márquez et al., 1999, 2016; Suarez et al., 2009; Montag et al., 2011; Ramírez-García et al., 2018). According to Vargas and de Sostoa (1996), predominance of females is common in fish with sexual dimorphism, this being the case of most of the Poeciliidae species.

Snelson and Wetherington (1980) in Poecilia latipinna as well as Chapman et al. (1991) in Poecilia gilli reported that sex ratios at birth are usually 1: 1, but by selective pressure (environmental characteristics of the habitat and seasonal mortality) result in adult sexual proportions biased towards one sex or another. Snelson (1989) suggested that the predominance of females can be attributed to differential mortality based on sex. Females have higher survival rates due to their larger size, longer life, less flashy colors, and greater resistance to the rigors of reproduction and unfavorable environmental conditions. Rosenthal et al., (2001) suggested that bright colors appear to be detrimental to the survival of poeciliid species and implied an increased risk of predation for males.

Recruitment. The proportion of juveniles (69.3\%) suggests that the recruitment intensity of L. zonata in Maimón River is high. The intensity of recruitment is known as the ratio between adult and juvenile organisms and /or subadults in a population (Zeug and Winemiller, 2008). This may be related to the ability of poeciliid females to give birth to live offspring, which increases their chances of survival, in addition, females can store viable sperm in the gonoduct and a single insemination may be sufficient to generate several consecutive broods (Constanz, 1989; Snelson, 1989). Winemiller and Rose (1992) pointed out that producing a large number of juveniles is a mechanism that leads to continuous entry of individuals, resulting in a high survival rate and population maintenance. 
Morphometry. A wide range of sizes was recorded (TL: 6.50-65.69 mm, SL: 4.38-53.59 mm), which suggests that the sampling methods and effort employed were efficient when capturing organisms of all possible sizes, in that sense it is assumed that a representation of the population sizes of L. zonata was obtained in the same proportion as they are found at the Maimón River, even so it should be noted that each fishing gear has a different selectivity, which influences species as well as the sizes that can be sampled. Lee et al. (1983) recorded a maximum SL for males of $3 \mathrm{~cm}(30 \mathrm{~mm})$ and for females of $3.2 \mathrm{~cm}(32 \mathrm{~mm})$. The maximum values for males and females reported in this study significantly exceed those values.

Cohen et al. (2015) reported for L. zonata females a mean SL of $32.5( \pm 1.0) \mathrm{mm}$ and for males $23.8 \mathrm{~mm}( \pm 0.2)$, from a population collected in the Yaque del Norte River, Santiago province.

A tendency of greater dimensions was observed for females, leading to a marked sexual dimorphism, which is not only expressed in coloration but also in size, as reported for most species of the Poeciliidae family (Bisazza, 1993). Farr (1989) found that the differential size of the family Poeciliidae is due to the fact that females take more time to mature and continue to grow throughout their life, while males exhibit an accelerated growth rate and do not grow much after reaching sexual maturity, and do not live long after they have matured (Snelson, 1984; Vargas and De Sostoa, 1996).

Relations between morphometric variables. The TL-SL relationship is of great relevance for future studies of the species, since it is not always possible to measure TL of the fish due to mechanical damage in the caudal fin. It is also useful to compare different studies that use different scales. The length-weight relationship (LWR) in fish is a very important classical tool in fisheries management and aquaculture. LWR have often been used to estimate weight from length, since direct weight measurements can be time consuming in the field (Sinovcic et al., 2004). In addition, they can allow the calculation of the biomass of the population, indirect estimation of the production and the condition or corporal well-being of the fish, as well as the indirect analysis of the rhythm of growth (Le Cren, 1951; Froese, 2006).

The relationship of standard length-total weight in L. zonata shows an $r^{2}$ of 0.929 , which suggests that the total wet weight (WEIGHT) can be estimated when the standard length (SL) of the fish is known with a prediction level of $92.3 \%$. The values of $b$ of the equations obtained for each group were significantly different. Bagenal and Tesch (1978) pointed out that the allometric coefficient $(b)$ of fish should be between 2.5 and 3.5; the coefficients recorded in this study are within this range. The value of $b$ for males of $L$. zonata was of 3.05 , which suggests an isometric growth. This suggests that male growth in length and weight are proportional, which is in agreement with the observation for the males of this species to have a more elongated body shape. By contrast, the females showed a $b$ value of 3.24, which suggests a positive allometric growth, which is a greater growth in weight than in length. This can be explained by the increase in weight that the females experience due to gonadal development and oocyte production.

Condition factor. The relative condition factor is based on the hypothesis that those fish with greater weight at a certain size are in better condition. A condition factor equal to or greater than one indicates a good level of feeding and good environmental factors (Ujjania et al., 2012). The average relative condition factor $(\mathrm{K} n)$ in this study was 1.11 , which suggests that as a population L. zonata are in good condition and experience favorable environmental conditions. Females showed better average condition (1.01) than males $(0.82)$. This can be attributed to the fact that they significantly increase their weight due to the development of embryos within the gonads (Nikolsky, 1963). Juveniles presented the best condition in this study (1.21), which may be due to the accelerated rate of growth they experience. 
These condition values cannot be considered definitive. Shifts in the condition factor may indicate variations related to gonadal development, feeding and fat accumulation of fish, and it is likely that fish of the same species, even of the same sex, will show different condition in different places and seasons (Le Cren, 1951). This is why this factor is not considered an absolute index of condition, but rather an interpopulation comparison tool that can be used in predictive models of population dynamics. This factor has greater potential when it is complemented with other direct studies such as an analysis of diet or reproductive activity (McPherson et al., 2011). There are no prior studies that address the status of any species of fish in the Dominican Republic, which prevents a comparative analysis. Therefore, this study provides an important basis for future studies and comparisons.

It should be considered that these data were collected in a short period of time and no temporal variation could be established. It is possible that the sex ratio as well as proportion of adults-juveniles, morphometric characteristics and body condition of the species vary significantly during the year, requiring long-term studies for a greater understanding of the effect of seasonality and environmental factors in these demographic parameters.

\section{CONCLUSIONS}

The population of Limia zonata on the Maimón River showed a sex ratio is biased towards females (1.0: 1.6). Juvenile fish were more frequent than adults (1.0: 2.3). The high proportion of juvenile individuals suggests a high intensity of recruitment. Ten size classes were distinguished; the most frequent was $14-18 \mathrm{~mm}(27.9 \%)$. The morphometry of the species varied significantly between the sexes, revealing a very marked sexual dimorphism. The females are significantly larger, taller and heavier than males. Length-weight relationships were significantly different among females and males, suggesting a positive allometric and isometric growth curve, respectively. The population of L. zonata in the Maimón River exhibits good body condition.

\section{LITERATURE CITED}

Bisazza, A. 1993. Male competition, female mate choice and sexual size dimorphism in poeciliid fishes. Marine \& Freshwater Behaviour \& Physiology, 23 (1-4): 257-286.

Bagenal, T. B., and F. W. Tesch. 1978. Age and growth methods for assessment of fish production in fresh waters. IBP handbook $\mathrm{N}^{\circ}$ 3. Blackwell Press. Oxford, pp. 101-136.

Burgess, G. H., and R. Franz. 1989. Zoogeography of the Antillean freshwater fish fauna. Biogeography of the West Indies: past, present, and future. Sandhill Crane Press, Florida, pp. 263-304.

Cabral, J. A., and J. C. Marques. 1999. Life history, population dynamics and production of eastern mosquitofish, Gambusia holbrooki (Pisces, Poeciliidae), in rice fields of the lower Mondego River Valley, western Portugal. Acta Oecologica, 20 (6): 607-620.

Canty, A., and B. Ripley. 2017. boot: Bootstrap R (S-Plus) Functions. R package version 1.3-20.

Chapman, L. J., D. L. Kramer, and C. A. Chapman. 1991. Population Dynamics of the Fish Poecilia gillii (Poeciliidae) in Pools of an Intermittent Tropical Stream. The Journal of Animal Ecology, 60 (2): 441-453. 
Cohen, S. N., J. U. Regus, Y. Reynoso, T. Mastro, and D. N. Reznick. 2015. Comparative life histories of fishes in the subgenus Limia (Pisces: Poeciliidae). Journal of Fish Biology, 87 (1): 100-114.

Constantz, G. D. 1989. Reproductive Biology of Poeciliid Fishes, 33-50 pp. In G. K. Meffe and F. F. Snelson Jr. (Eds.), Ecology and Evolution of Livebearing fishes (Poeciliidae), Englewood Cliffs, New Jersey, United States.

Contreras-MacBeath, T., and H. R. Espinoza. 1996. Some Aspects of the Reproductive Strategy of Poeciliopsis gracilis (Osteichthyes: Poeciliidae) in the Cuautla River, Morelos, Mexico. Journal of Freshwater Ecology, 11 (3): 327-338.

Farr, A. J. 1989. Sexual selection and secondary sexual differentiation in poeciliids: Determinants of male mating success and the evolution of female choice, 91-123 pp. In G. F. Meffe and F. F. Snelson Jr. (Eds.), Ecology and Evolution of Livebearing fishes (Poeciliidae), Englewood Cliffs, New Jersey, United States.

Fisher, R. A. 1930. The Genetical Theory of Natural Selection. Clarendon Press, Oxford, 272 pp.

Froese, R. 2006. Cube law, condition factor and weight-length relationships: history, meta analysis and recommendations. Journal of applied ichthyology, 22 (4): 241-253.

Gómez-Márquez, J. L., J. L. Guzmán-Santiago, and A. Olvera-Soto. 1999. Reproduction and growth of Heterandria bimaculata (Cyprinodontiformes: Poeciliidae) in the Laguna “El Rodeo", Morelos, Mexico. Revista de Biología Tropical, 47 (3): 581-592.

Gómez-Márquez, J. L., B. Peña-Mendoza, I. H. Salgado-Ugarte, A. K. Sánchez-Herrera, and L. Sastré-Báez. 2008. Reproduction of the fish Poeciliopsis gracilis (Cyprinodontiformes: Poeciliidae) in Coatetelco, a tropical shallow lake in Mexico. Revista de Biología Tropical, 56 (4): 1801-1812.

Gómez-Márquez, J. L., B. Peña-Mendoza, and J. L. Guzmán-Santiago. 2016. Reproductive biology of Poecilia sphenops Valenciennes, 1846 (Cyprinidontiformes: Poeciliidae) at the Emiliano Zapata Reservoir in Morelos, Mexico. Neotropical Ichthyology, 14 (2): 1-9.

Hamilton, A. 2001. Phylogeny of Limia (Teleostei: Poeciliidae) based on NADH dehydrogenase subunit 2 sequences. Molecular Phylogenetics and Evolution, 19 (2): 277-289.

Haskins, C. P., E. F. Haskins, J. J. A. McLaughlin, and R. E. Hewitt. 1961. Polymorphism and population structure in Lebistes reticulatus, a population study, 320-395 pp. In C. G. Sibley and W. F. Blair (Eds.), Vertebrate Speciation. University of Texas Press, Texas.

Le Cren, E. 1951. The length-weight relationship and seasonal cycle in gonad weight and condition in the perch (Perca fluviatilis). The Journal of Animal Ecology, 20: 201-219.

Lee, D. S., S. P. Platania, and G. H. Burgess. 1983. Atlas of North American freshwater fishes, 1983 supplement. Occasional Papers of the North Carolina Biological Survey no. 1983-6. North Carolina State Museum of Natural History, Raleigh, N.C., 67 pp.

McPherson, L. R., A. Slotte, C. Kvamme, S. Meier, and C. T. Marshall. 2011. Inconsistencies in measurement of fish condition: a comparison of four indices of fat reserves for Atlantic herring (Clupea harengus). iCES Journal of Marine Science, 68: 52-60. 
Ministerio de Medio Ambiente y Recursos Naturales de República Dominicana. 2011. Lista de Especies en Peligro de Extinción, Amenazadas o Protegidas de la República Dominicana (Lista Roja), 44 pp. Santo Domingo, República Dominicana.

Minitab 18 Statistical Software, [Computer software]. 2016. State College, PA: Minitab, Inc.

Montag, L. F. A., T. M. Freitas, D. O. Raiol, and M. V. da Silva. 2011. Length-weight relationship and reproduction of the guppy Poecilia reticulata (Cyprinodontiformes: Poeciliidae) in urban drainage channels in the Brazilian city of Belém. Biota Neotropica, 11 (3): 93-97.

Nikolsky, G. V. 1963. The Ecology of Fishes. New York, Academic Press, 352 pp.

Parenti, L. R. 1981. A phylogenetic and bioeographic analysis of Cyprinodontiform fishes Teleostei, Atherinomorpha. Bulletin of the American Museum of Natural History, 168 (4): 341-557.

Ramírez-García, A., J. P. Ramírez-Herrejón, M. Medina-Nava, R. Hernández-Morales, and O. Domínguez-Domínguez. 2018. Reproductive biology of the invasive species Pseudoxiphophorus bimaculatus and Poecilia sphenops in the Teuchitlán River, México. Journal of Applied Ichthyology, 34 (1): 81-90.

Rauchenberger, M. 1988. Historical biogeography of poeciliid fishes in the Caribbean. Systematic Zoology, 37 (4): 356-365.

R Core Team. 2016. R: A language and environment for statistical computing. R Foundation for Statistical Computing, Vienna, Austria. Available in: http://www.R-project.org/.

Reza, U. B. S., and P. E. Díaz. 1994. Algunos aspectos de la biología reproductiva de Heterandria bimaculata (Poeciliidae). Resúmenes IV Congreso Nacional de Ictiología de Morelia, 57-58 pp. Michoacán, México.

Rodríguez-Peña, C. M. 1997. Phylogenetic analysis of the tribe Poeciliini (Cyprinodontiformes: Poeciliidae). Copeia, 1997 (4): 663-679.

Rosenthal, G. G., T. Y. Flores-Martínez, F. J. García de León, and M. J. Ryan. 2001. Shared preferences by predators and females for male ornaments in swordtails. The American Naturalist, 158 (2): 146-154.

Sinovčić, G., M. Franičević, B. Zorica, and V. Čikeš Keč. 2004. Length-weight and lengthlength relationships for 10 pelagic fish species from the Adriatic Sea (Croatia). Journal of Applied Ichthyology, 20 (2): 156-158.

Snelson, F. F. Jr., and J. D. Wetherington. 1980. Sex ratio in the sailfin molly, Poecilia latipinna. Evolution, 34 (2): 308-319.

Snelson, F. F. Jr. 1984. Seasonal maturation and growth of males in a natural population of Poecilia latipinna. Copeia, 1: 252-255.

Snelson, F. F. Jr. 1989. Social and environmental control of life history traits in poeciliids, pp. 149-161. In G. K. Meffe and F. F. Snelson Jr. (Eds), Ecology and Evolution of Livebearing Fishes (Poeciliidae). Prentice-Hall, Englewood Cliffs, New Jersey. 
Sturges, H. A. 1926. The choice of a class interval. Journal of the America Statistical Association, 21: 65-66.

Turner, J. S., and F. F. Snelson, Jr. 1984. Population structure, reproduction and laboratory behaviour of the introduced Belonesox belizanus (Poeciliidae) in Florida. Enviromental Biology of Fishes Journal, 10 (1): 89-100.

Ujjania, N. C., M. P. S. Kohli, and L. L. Sharma. 2012. Length weight relationship and condition factors of Indian major carps (C. catla, L. rohita and C. mrigala) in Mahi Bajaj Sagar, India. Research Journal of Biology, 2 (1): 30-36.

Vargas, M. J., and A. De Sostoa. 1996. Life history of Gambusia holbrooki (Pisces, Poeciliidae) in the Ebro delta (NE Iberian Peninsula). Hydrobiology, 341 (3): 215-224.

Weaver, P. F., A. Cruz, S. Johnson, J. Dupin, and K. F. Weaver. 2016. Colonizing the Caribbean: biogeography and evolution of livebearing fishes of the genus Limia (Poeciliidae). Journal of Biogeography, 43 (9): 1808-1819.

Winemiller, K. O., and K. A. Rose. 1992. Patterns of life-history diversification in North American fishes: implications for population regulation. Canadian Journal of Fisheries and Aquatic Sciences, 49 (10): 2196-2218.

Zeug, S. C., and K. O. Winemiller. 2008. Relationships between hydrology, spatial heterogeneity, and fish recruitment dynamics in a temperate floodplain river. River Research and Applications, 24 (1): 90-102.

Zúñiga-Vega, J. J., A. L. Hernández-Rosas, A. Molina-Moctezuma, H. A. Pérez-Mendoza, F. R. Rodríguez-Reyes, Y. M. Bravo-Espinosa, and H. Espinosa-Pérez. 2012. Population abundance and sex ratio of the viviparous freshwater fish Poeciliopsis baenschi (Poeciliidae) throughout its range in western Mexico. Western North American Naturalist, 72 (3): 357-368.

[Recibido: 17 de abril, 2018. Aceptado para publicación: 20 de noviembre, 2018] 